\title{
The Hula Valley (Israel): From Nature to Anthropogenic Management, A Review
}

\author{
Moshe Gophen ${ }^{a^{*}}$ \\ a Senior Scientist, Migal-Scientific Research Institute, Kiryat Shmone Israel. Phone: +972-505-399-540. \\ *Corresponding author's email address: gophen@migal.org.il
}

\section{A R T I C L E I N F O}

Received: 02-06-2016

Accepted: 04-07-2016

Available online: 09-07-2016

Keywords:

Agriculture;

Anthropogenic;

Hula; Intervention;

Settling.

JEL Classification:

Environmental; Impact

\begin{abstract}
A B S T R A C T
The Hula Valley is presently a subject with an integration into national economy, management of water supply, agriculture and tourism management Therefore, the long history, from Stone-Age period until present, of settling in the Hula Valley is reviewed by scientific documents survey. This Valley land, 17.7X103 ha, was mostly covered by swamps and old Lake Hula. Population size of settlers in the Valle and in close vicinity was very small. The swamps in the Valley were mostly (app 85\%) covered by Cyperus papyrus vegetation. Three major headwaters discharges were fluxed through the swampy area into Lake Hula from which the Jordan river outflow continued downstream into Lake Kinneret. Anthropogenic usage of the Hula Valley hydrological and vegetation (Papyrus for mats production and grass for cattle grazing) resources were poorly implemented. During the 1950 `s of the 20th century the swamps and the Hula Lake were drained and the entire valley land was converted into agricultural utilization. The significance of that environmental modification consequently predict successful improved enhancement of the anthropogenic intervention.
\end{abstract}

This is an open access article under the terms of the Creative Commons Attribution License 4.0, which allows use, distribution and reproduction in any medium, provided the original work is properly cited.

DOI: http://dx.doi.org/10.18533/rss.v1i7.42 ISSN: 2378-8569 (Print), 2378- 8550 (Online)

\subsection{Introduction}

\section{$1.1 \quad$ Background and idea of the study}

The geographically "Hula Valley" is situated at the Northern part of the Israeli section of the big Syrian-African Rift Valley stretching along the Eastern side of the country. The Western and Eastern sides of the Hula Valley are surrounded by the Rift Valley steeply slops of the mountain margins. The Northern and the Southern boundaries of the valley are situated at the altitude levels of 200 and 60 MASL respectively. The length and width of the valley are 25 and $6 \mathrm{Km}$ respectively. The Northern part is however wider $(8 \mathrm{Km})$. The total area of the valley is $17.7 \times 10^{3}$ ha (Karmon 1956).

The Hula Valley ecosystem has undergone significant changes of which the major was the drainage of old Lake Hula and the swamps carried out during the 1950`s. The natural ecological structure of the valley encompassed an old Lake Hula ( $1.4 \times 10^{3}$ ha) located in the Southern part of the Valley. At the Northern side of the lake, there was an adjacent swampy area with total area fluctuating between $2.1 \times 10^{3}$ ha in summer and $6.0 \times 10^{3}$ ha in winter (Dimentman et al 1992). The rest of the Northern part of the valley varied between 11.7 X10 $3 a$ and 15.6 $\mathrm{X} 10^{3}$ ha in winter and summer respectively. 


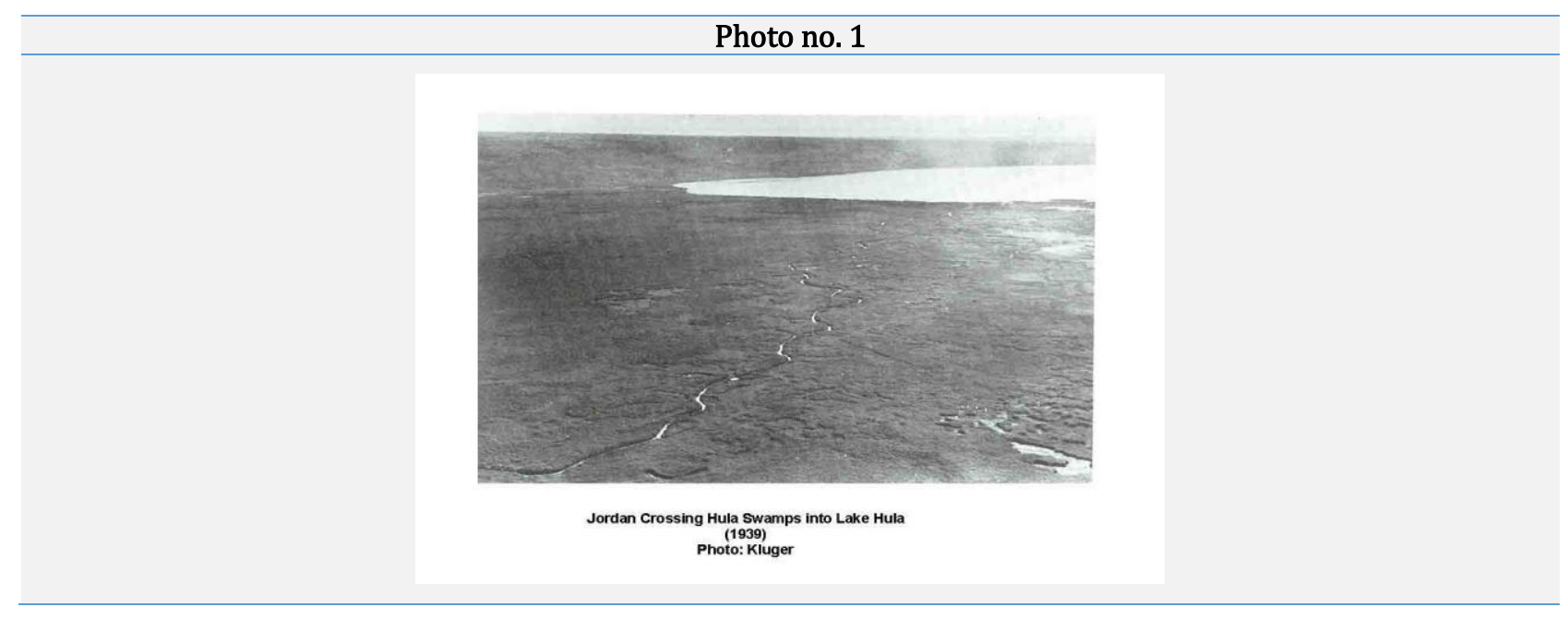

Three rivers such as: Hatzbani, Banyas and Dan, flowing from north to south down from Mount Hermon connected together with several other streams, forming the Jordan River. The River Jordan crossed the swampy area through 3 major tributaries while flooding the swamps, and combined into one Lake Hula inlet. From Southern Lake Hula, one outlet flows downstream into Lake Kinneret. Further on to the South, there was a Bazalt "vein" which formed a discharge partial stopper causing the River Jordan continuing discharge yield with lowering and increasing floods level in the valley. In the summer, the difference between the rivers inflow and outflow from the valley was negative due to evaporation and underground infiltration of surplus water. The outcome was that Lake Hula Water Level declined and there was reduction of the swampy area. In the winter time, the balance was highly positive causing an increase of Lake Hula Water Level and expansion of the swampy area.

\subsection{The uniqueness and importance of the study}

A comprehensive compilation of the inventories of the fauna, flora, and physico-chemical and hydrological conditions of Lake Hula was documented by Dimentman et al. (1992) as well as the history of the research focusing mainly on the Lake. During the period before drainage (1851-1958), more than 50 scientists, travelers, natural items collectors and surveyors visited the Valley and documented environmental inventories which they collected from and around the lake. They published reports about the Hula biota and hydrology. Moreover, according to those reports (excluding synonyms and changes of taxonomical identities), more than 1000 species of invertebrates, 60 species of fishes, 7 amphibians, 9 reptiles, 4 mammalians and more than 200 species of birds were documented. The current paper focuses on anthropogenic management and life trait of Hula Valley residents before drainage with respective view to the present.

\subsection{Methodology}

A compilation of published documentation including surveyor reports, scientific papers and reports which cover a long term period was carried out.

\subsection{The main finding are the followings}

\subsection{Settling History in the Hula valley}

The natural conditions in the Hula Valley Land Ecosystem were very attractive for human settling throughout long history and even up to the present. The Human integration with the Hula Valley Ecosystem structure was rather optimal and permanently accompanied by struggle for the accomplishments of society welfare improvements. The ecological services and the integration between human and natural conditions were optimal: fertile soil and water sufficiency enabled integrative trait of the life between the Human Society and the environment. Moreover, human settling in the Hula Valley and the agricultural development did not cause restriction of the Swampy area. On the contrary, an expansion occurs when settlers did not maintain appropriate usage of water for irrigation. Population densities were enhanced when water utilization was properly carried out and were diluted when irrigation was operated inappropriately. Human life in the Hula Valley tackled several difficulties, including Malaria. It is not yet clear if Malaria existed historically in the Hula Valley, nevertheless, the diseases was well known during the 100-200 years before drainage and mostly related to appropriate usage of water for irrigation followed by essential drainage of surplus water. 
The Stone Age_culture was studied trough excavated sites located in several terrestrial sites in the Hula Valley. In the Gesher Bnot Yaakov (GBY) site located on the Jordan bank close to the Southern end of the valley, the "Abbeville" culture was discovered and documented. The Stone Age sites of Maayan Baruch located in the Northern part of the Hula Valley at an altitude of 230 MASL, as well as the Mesolithic Period age of Einan (80 MASL) and Kfar Hanasi (125 MASL) sites on both sides of the valley. Thousands of Chalcolithic Single Chamber Megalithic Tomb, "Dolmens", were documented on the Eastern slops of the Hula Valley and on the Golan Heights, on the Eastern Hula Valley Plateau, the Golan Height.

More than 20 settling sites aged as Bronze - Iron Periods were uncovered in the Hula Valley indicating permanence occupation strategy. Those settlements were allocated about 5-15 $\mathrm{m}$ above the land valley surface in the vicinity of the old Lake Hula or Rivers inlet fan zones. The Hula Valley was densely inhabited by the Israelis with the regional city centers (such as Laish-Dan) located outside, in close vicinity to the valley. After the destruction of the $1^{\text {st }}$ Temple, most of the Hula Valley population was deported. For the next 500 years, the Hula Valley was not inhabited.

During the 332 - 63 BC period, the entire territory of Israel, particularly, the Hula Valley was under the control of Alexander the Great, Persians, Ptelomy, the Sleucids, Romans and Hasmoneans. The cultural trait of the Hula Valley inhabitants was Urban-Hellenistic where small settlements were under the impact of local big cities. The Hula agricultural development was developed into farming type.

Farms produce was supplied to non-agricultural settlements. The major crops were Papyrus handcrafts and red color rice irrigated by network of open canals. The historian Roman Commander, Josephus Plavius documented details about Lake Hula and the swamps. It is also indicated that hydrological network within the Hula Valley was different from the pattern we presently observe. After the destruction of the $2^{\text {nd }}$ Temple and the Israelis deportation followed by Christian persecution the Hula Valley as the population, as well as in the entire Galilee region, was extremely diluted.

\subsection{Middle ages period}

For a period of more than 1000 years, the Hula Valley Ecosystem was very poorly surveyed, studied and documented. Mukaddassi (985 AC) (Karmon 1956) describe the city of Banias surrounded by small villages cropping Rice and Cotton and utilizing Papyrus for handcraft products produced by local residents. El Jubair (1185 AC) (Karmon 1956) documented wide area cultivated by local people to be supplied to the nearby city of Hunin. The big livestock diary herds grazing in the Hula Valley were also documented. The first documentation of Water Buffalo in Hula bodies of water is given by Willibald (754 AC) (Karmon 1956).

The documentations of cattle grazing of green grass vegetation in between water flows in the Hula Valley were widely presented (1300, 1160 AC) (Karmon 1956). It is suggested (Karmon 1956) that the Hula Valley population was flourished until mid-13 th $(1240 \mathrm{BC})$ century AC, when the Mongolians invaded. The Mongolians destructed the irrigation system networks and completely deported the Hula Valley population, while in other parts of the country, farms and agricultural production recovered. In 1260 the Governor Bibars constructed the bridge over the River Jordan, Southern of Lake Hula creating significant elevation of water level in the Hula Lake and swamps. Later on, after 500 years, the Hula Valley was just a desolate area of lake and swamps highly infected by Malaria under the control of the Ghawarna Beduins. Karmon (1956) concluded that the Hula Valley was turned into a wilderness by the Mongolian from 1240 AC.

Karmon (1956) also suggested that the Malaria was introduced into the Hula Valley by the Crusaders and inundation of the Hula Valley was enhanced as a result of the construction of Benot Yaakov Bridge downstream by Baibars the Sultan of Egypt (1260-1277) probably in 1260. During the next 500 years, the Hula Valley was a desolate land partially covered by swamps and a lake where Malaria was widespread and controlling the density of Beduins tribes' population. There were no settlements, but only nomad inhabitants which moved out of the valley during summer time and came back into the valley for sowing of sorghum and rice planting.

Arab population came down into the valley for cattle grazing and summer sowing of corn and rice planting. Due to political instability, the agricultural development was sometimes replaced by cattle grazing. Information on settling and life conditions in the Hula Valley during the $18^{\text {th }}-20^{\text {th }}$ centuries was widely documented by 16 travelers and pilgrims who surveyed this region and was summarized by Ritter (1850) as well as by scientists who documented the natural life in the valley. 


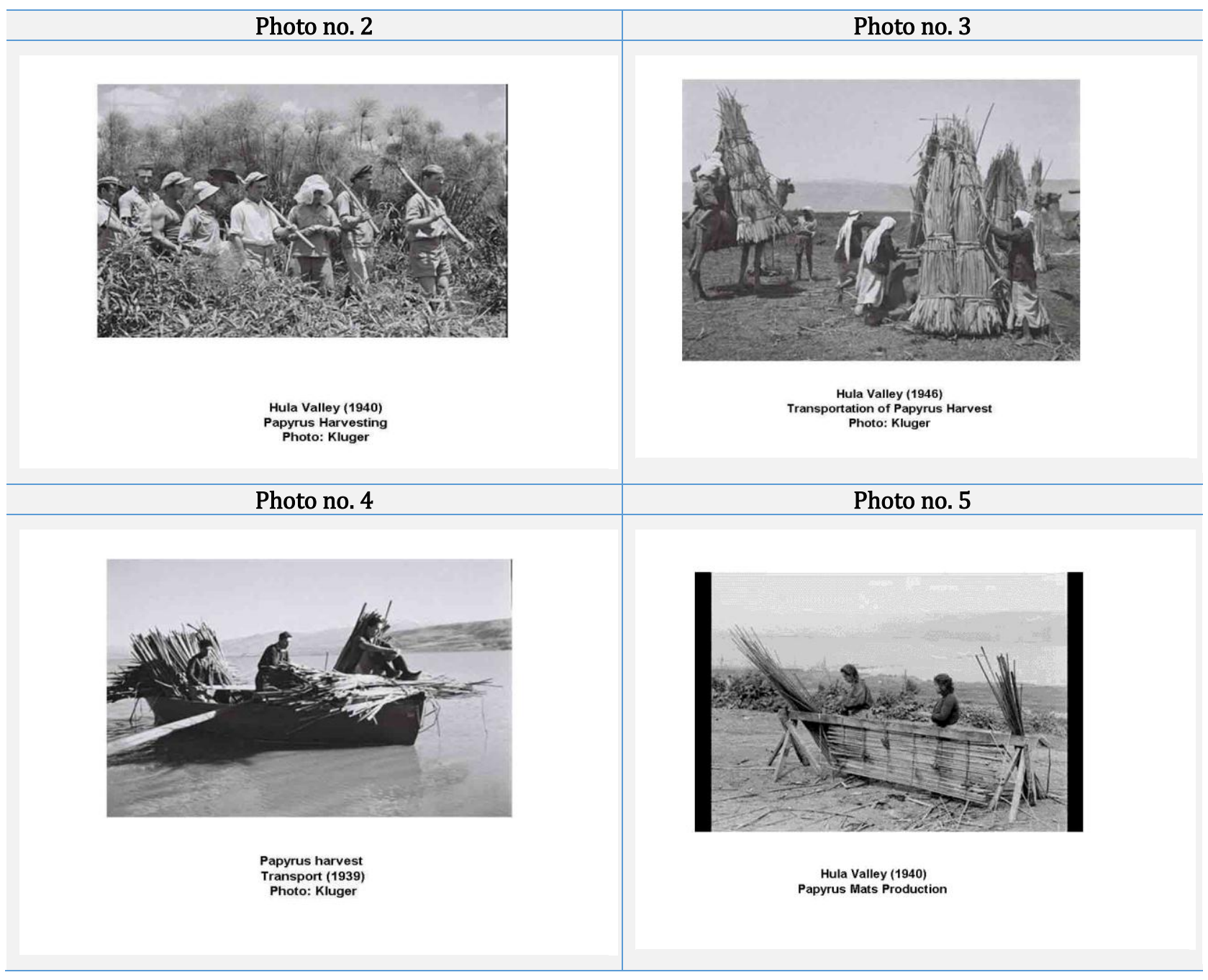

\subsection{Rise and fall of the Ghawarna culture in the Hula valley}

Settling in the Hula Valley by the Ghawarna tribes, was initiated during the $4^{\text {th }}$ decade of the $19^{\text {th }}$ century and abruptly came to an end in 1948. The development of the Ghawarna settling was very slow during the $19^{\text {th }}$ century and significantly accelerated during the $1^{\text {st }}$ half of the $20^{\text {th }}$ century. British sources reported that during 1877, 520 and 12400 in 1935, the Ghawarna residents were settled in the Hula Valley. In 1941 13350, the residents were documented and in 1948 - 31740. Much of the information about the Ghawarna population was documented by, the European, Turkish, Jewish, and British sources. The Arab communities in the Hula Valley did not contribute any scripts for the next generations. Prior to 1830, there were no permanent settlements of Ghawarna in the Hula Valley. Residents from the region came down from surrounded mountains with their cattle herds for grazing and for agricultural cropping in summer time and stayed most of the summer months in those parts of the valley, which were not inundated. This was the summer paradox of the Hula wetlands prior to the $20^{\text {th }}$ century: the drier the winter, the more grass for cattle grazing and the land for agriculture were available. The cultivated land was like a puzzle of plots, which are "Mazraa" (or Azeva). The property of the Ghawarna was Water Buffalo and the seasonal activity was due to sowing of corn, rice and wheat. The widespread vegetation of Cyperus papyrus L. was managed by both harvest and intended fire under control. The stems of the harvested C. papyrus were used for mats production for hut walls and floor padding. The vegetation of Papyrus stems and sub-surface rhizomes were also utilized as fuel for heating and cooking. The construction of canals for the convey of irrigation water was common. The political improvements conditions during the $19^{\text {th }}$ century enhanced migration of population from big villages and towns on the Golan Heights down to the Hula Valley. The Ghawarna Beduins also introduced cattle based on grass grazing in the region around the swamps. During mid-19th century deterioration of political conditions and Malaria distributions resulted population dilution. The Significant changes of Hula Valley management occur during the $2^{\text {nd }}$ half of the $19^{\text {th }}$ century (Tristram 1863). Field crops of wheat, barley and cotton, on the newly developed land blocks were enhanced. In Conclusion, after 5 centuries of desolate, the Hula Valley settling of Human Being was renewed as a result of the improvement of social structure which led to an organized activity of irrigation and drainage canal constructions. Nevertheless, the success of settling implementation in the Hula Valley was not possible without the volunteers who came from unpredicted social sources to establish their living home on the Hula Valley land. 
At the end of the $19^{\text {th }}$ century, settling of the Jews was initiated in the Hula Valley while still under active Malaria infectious distribution. Here and there, housing construction included also stone usage. In 1878, 13 villages were recorded in the Hula Valley including 1000 residents but significant restriction of agricultural development. Several unsuccessful experiments of Hula waters drainage were carried out. The population of the Hula Valley was enhanced up to 3000-4000 residents accompanied by agricultural developments of grain crops (Barley, Wheat, Corn, and Sorghum) and rice. Uncultivated land was utilized for cattle grazing and the initiation of orchards appeared. Mats production made of Papyrus stayed popular. Nevertheless during 1906 - 1918 anthropogenic activity was small.

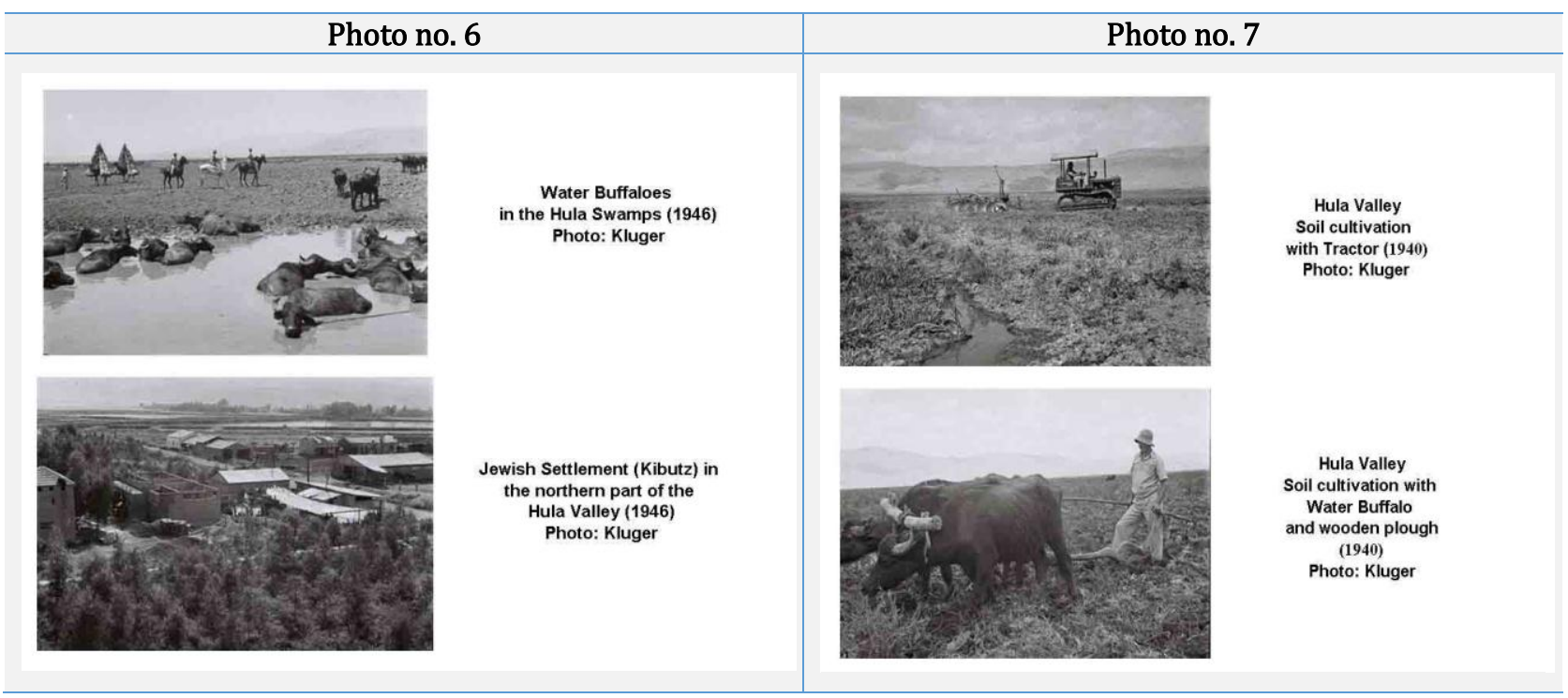

Anthropogenic activities during the period of the Palestine British Mandate control (1918 - 1948$)$ were indicated as intensive by the Jews and poorer by Arab community. New Jewish settlements were established in the close vicinity of the Hula Valley attracting residents. The major source of income for the newly emigrated residents was agricultural development in the Hula Valley. All throughout this period, fighting Malaria was a major issue of concern. Malaria was a critical threat to the existence of the Hula Valley population: 60-80\% of all children were infected and $60-100 \%$ of those below 10 years of age (Karmon 1956). Intensive preventive Malaria operations were objected by the local residents and later became more. Having been very effective since the DDT usage. Political pressures between Jews and Arabs were common.

At the end of the $30^{\text {th }}$ decade (1937), the total cultivated area in the Hula Valley respective to population size was low. Major agricultural branches were field crops, Water Buffalo raising and Papyrus mats production. About 6000 (2 per family) water buffalos were recorded, and mats production was mostly done by women. The Arab settlement History in the Hula Valley continued for about 100 years. It was indicated that their settling was un-intended and was due mainly to society refugees who were unable to get a better home site. Most of them were vanished by Malaria. Nevertheless, the population size slightly increased and was accompanied by swamps drainage to enhance the developed land during limited periods. The battle between nature and human society was concluded by nature victory, because the Arab settler (Ghawarna) did not have the knowledge, self-desire and appropriate facilities to be the winner. This was the function attributed to the Jewish settlers. During 18841934, there was only one Jewish Village in the Hula Valley, Yesud HaMaala. During 1939 - 1942,7 Jewish settlements were established in the Northern part of the Hula Valley and on the Eastern and Northern Foot-hill zone of the Valley slope; during 1942 - 1947 more 5 Jewish settlements were added; the total residents number was 2700.Their major income resource was agricultural crops cultivated on the land of the Hula Valley. The total cultivated area was 2931.4 ha and about 1800 livestock animals. After the independent war (1948 - 1949), the Arab residents were evacuated from the Hula Valley. The $1^{\text {st }}$ stage of the Jewish settling in the Hula Valley, 1942 - 1949, was indicated as an accomplishment of the Malaria avoidance struggle together with the initiation of the establishment of agricultural management in the Hula Valley. Several new branches of agricultural crops were successfully commercially introduced, including international export, such as: Cotton, Aquaculture Fishery, Vegetable, Alfa Alfa, Sun Flower, etc. The drainage of the Hula Valley was completed in 1957. During the period of 1949 - 1957 Malaria was completely vanished, agricultural technologies were improved and drainage project was design and implemented.

\subsection{Environmental condition: Past and present}




\subsection{Water balance}

Water budget for the Hula Valley in mid-1940`s (Neuman 1955) is presented in Table 1:

\begin{tabular}{lr}
\hline Table 1: Water Balance $(\mathrm{mcm} / \mathrm{y})$ & $\left(\begin{array}{c}\left(0^{6} \mathrm{~m}^{3} / \mathrm{y}\right) \text { for the Hula Valley: } \\
(\mathrm{Neuman} 1955)\end{array}\right.$ \\
\hline Gain & $\mathrm{mcm} / \mathrm{y}\left(10^{6} \mathrm{~m}^{3} / \mathrm{y}\right)$ \\
\hline Inflow & 490 \\
Direct Rain on Lake \& Swamps & 25 \\
Rivers Runoff inflow & 140 \\
Total & 655 \\
Loss & \\
Lake Evaporation & 25 \\
Swamps Evapo-Transpiration & 35 \\
Total outflow & 595 \\
Total & 655 \\
\hline
\end{tabular}

The surface area of Hula Lake $-1.4 \times 10^{3}$ ha during winter time.

The swampy area varies between $5.4 \times 10^{3}$ ha in late winter to $0.7 \mathrm{X} 10^{3}$ ha at late summer.

Annual Rain Precipitation - $440 \mathrm{~mm} / \mathrm{y}$.

Annual Evaporation from Lake Hula $-168 \mathrm{~cm}$

Annual Evapo-Transpiration from the swampy area $-150 \mathrm{~cm}$

If simple direct relations are considered between water surface area and evaporation, the following are concluded:

Lake Hula surface evaporation- $25 \mathrm{mcm} / \mathrm{y}\left(10^{6} \mathrm{~m}^{3} / \mathrm{y}\right)$; If the lake would be converted into $10 \mathrm{~m}$ width (5.3 $\mathrm{Km}$ length) open canal, predicted evaporation $(168 \mathrm{~cm} / \mathrm{y})$ would be $1 \mathrm{mcm} / \mathrm{y}\left(10^{6} \mathrm{~m}^{3} / \mathrm{y}\right)$. Assuming dried lake area stay bare, $24 \mathrm{mcm} / \mathrm{y}\left(10^{6} \mathrm{~m}^{3} / \mathrm{y}\right)$ are saved. Nevertheless, the concept of lake drainage would be probably aimed at release land for irrigated agricultural usage; therefore, saving would be even smaller. Similar computation might be relevant to the swampy area: Evapo-Transpiration from the swampy area-35 X103 (Neuman 1955); If all bodies of water in this area would be converted into 2 major Canals (2.0 ha) and $90 \mathrm{Km}$ of internal drainage canals ( $45 \mathrm{ha}$ ) transpiration will be approximated as about $1 \times 10^{6} \mathrm{~m}^{3} / \mathrm{y}$.

Therefore, saving is potentially approximated as $33 \mathrm{X} 10^{6} \mathrm{~m}^{3} / \mathrm{y}$ and not if the land is utilized for agricultural development. In conclusion, swamps and lake drainage followed by agricultural land usage maintain insignificant water saving.

The old Lake Hula was utilized for intensive fishery throughout historical times, but mostly during the last decade before drainage. Nine fish species were fished for local consumption and marketing. The major landings were due to Tristrramellids, Cichlids and Catfishes while during late 1950`s Common Carps was enhanced (Dimentman et al 1992).

\begin{tabular}{c|}
\hline Photo no. 8 \\
\hline Photo no. 10
\end{tabular}




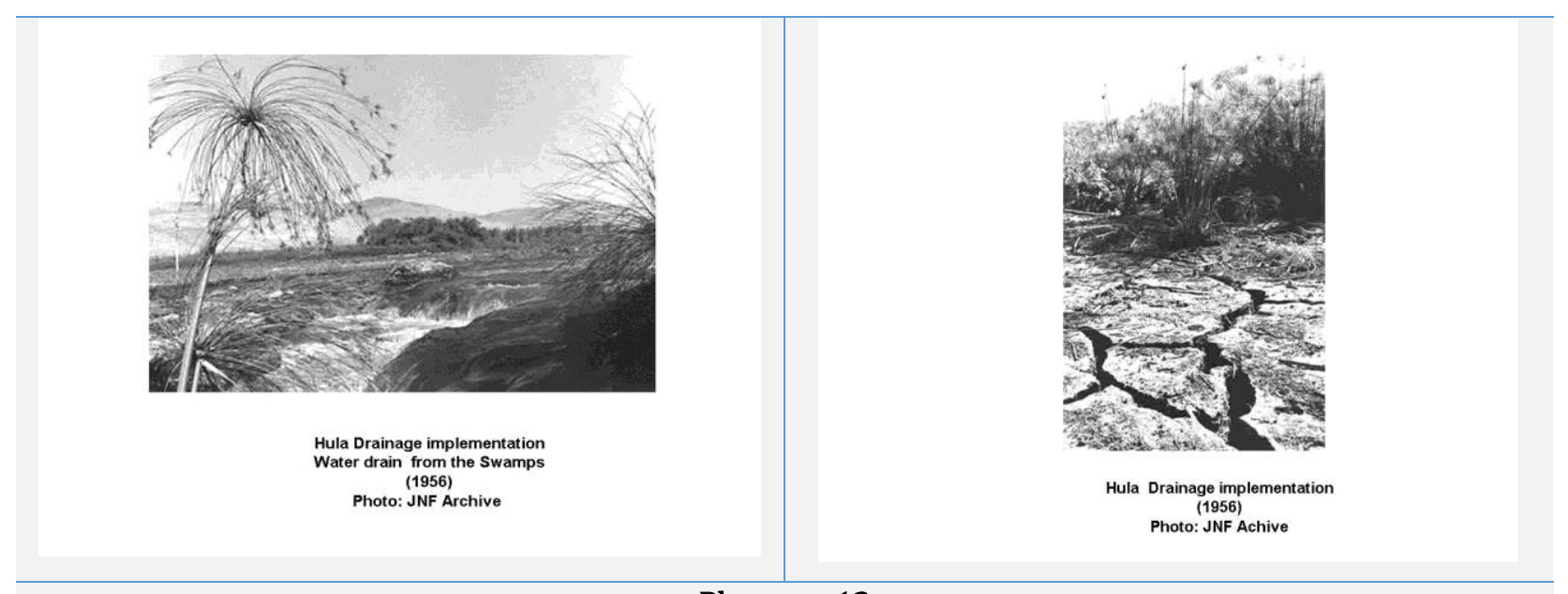

Photo no. 12

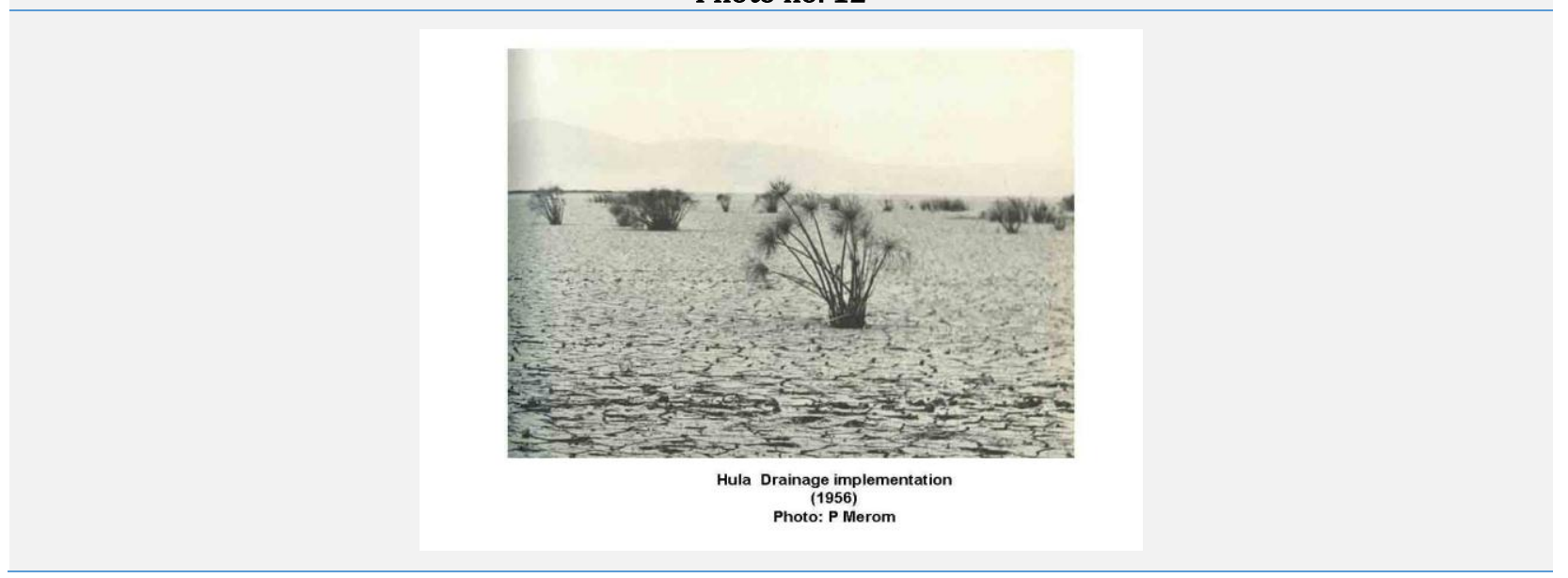

\subsection{History of the drainage implementation (Ben-Porath and Minsker 1996)}

During 1873 - 1957, 11 drainage proposals were proposed but not implemented. Eight proposals of drainage were designed but only 3 were implemented: 1) Deepening of the southern bottle neck was implemented 4 times during 1837-1887; 2) Combined proposal of deepening the southern outlet level and regulation of the Jordan inlet zone at the Northern end of Lake Hula,; 3) Jordan by-pass on both sides of the Hula Valley. During 1935-1947, a survey was carried out in the Hula Valley combined with a comprehensive plan for settling new emigrant refugees in Palestine. The $2^{\text {nd }}$ world war and the Independence war together with financial difficulties caused a delay of the Drainage proposal implementation to the 1950 `s. The implementation of the final plan was completed in 1958. This final design included two major open canals, the Eastern and Western, within-between network of drainage canals, and removal of the drain bottle neck formed by the Bazalt - Barrier- Block which crossed the Jordan River rout located at the south end of the Hula Valley. Nevertheless, 4 times during the Osmanli Imparatorlugu (Turkish Administration Control) period (1837 - 1917) un-successful implementations of Hula Valley drainage were carried out $(1837,1857,1863$, and 1877). During the British Mandate Control in Palestine, more than 10 proposals were designed but none of them was implemented. The practical achievement of the drainage proposal was operated during 1950-1957 (Ben-Porath and Minsker 1996).

\subsection{Summary of post drainage development (Gophen et al. 2014; Gophen 2015a, b; 2016)}

The Hula Valley research beyond drainage accomplishment was mostly aimed at both, in its impact on Lake Kinneret water quality and agricultural cropping improvement. The River Jordan contributes about $63 \%$ of the Kinneret water budget and more than $70 \%$ of nutrient inputs. There is very little information on nutrient fluxes originated from the Hula Valley through Jordan River into Lake Kinneret before drainage (Dimentman et al 1992). It is proposed that input of available Nitrogen was high before the Hula drainage, since the dominant Nitrogen species was Ammonia of which bio-availability is higher than the presently common Nitrogen species of Nitrate. Long term records documented Nitrate and organic Nitrogen as dominant species in the present Jordan loads. 
The Hula Lake and swamps were drained and more than 6500 ha were turned over to agricultural use to serve as an income source for residents of the Northern part of Israel. During the following 40 years, the drainage area was successfully cultivated and the agricultural products (mostly Cotton, Corn, Alfa - Alfa and vegetables) were economically produced and nutrient flux into Lake Kinneret did not threaten its water quality. Nonetheless, as a result of unsuitable management, drainage canals were blocked; irrigation methods were not suitable for optimal soil structure protection and water table declined. Consequently, soil structure of upper layers $(0-0.5 \mathrm{~m})$ was deteriorated and heavy dust storms occurred quite often in fall and spring by regional East wind (Sharkiya) which resulted in subsidence of soil surface (averaged as 7-10 cm/year) and blocking of drainage canals occurred. Due to the decline of water table level, lowering of soil moisture, longer time duration of uncovered soil by vegetation (agricultural crops or weeds) and unsuitable agricultural management, outbreaks of underground fire occurred frequently in the summer time and a lot of water was needed for extinguishing, which enhanced nutrient flux into Lake Kinneret. Rodent population outbreak caused severe damage to agricultural crops and stability of drainage canal banks. Part (500 ha) of the dried area, located at the lowest altitude in the Valley, went through processes causing extreme soil deterioration and subsidence which made it impossible for beneficial maintenance and thus, was not cultivated and the threat on Kinneret water quality was enhanced.

Consequently, a reclamation project (1990 - 1997) aimed at the reduction of nutrient fluxes from Hula soil, while continuing the economical utilization of the land by partial modification from agriculture to ecotourism utilization, was proposed and implemented. The concept of the new land use included man made structural changes of the system by integration between human welfare and natural elements of fauna and flora. The reclamation project, included increasing the level of soil moisture by elevating the water table, changing the irrigation system and renewing the hydrological (drainage) system throughout the entire valley. Ninety km of drainage canals were reconstructed and a shallow Lake Agmon ( 0.6 average depth; 110 ha area) was created as a waste water collector and recreational site. A plastic sheet (4 mm thickness) was placed vertically $(0-4.5 \mathrm{~m})$ along $2.8 \mathrm{~km}$, across the Western part of the valley, flows downstream to Lake Kinneret to prevent underground. The present Hula Valley management is a package deal between three sectors: 1) the land owners (farmers) that the Hula Valley area is a source of income for them; 2) Water managers which are responsible for the limnological protection of Lake Kinneret for drinking water supply; and 3) the "greens" Nature ecologists.

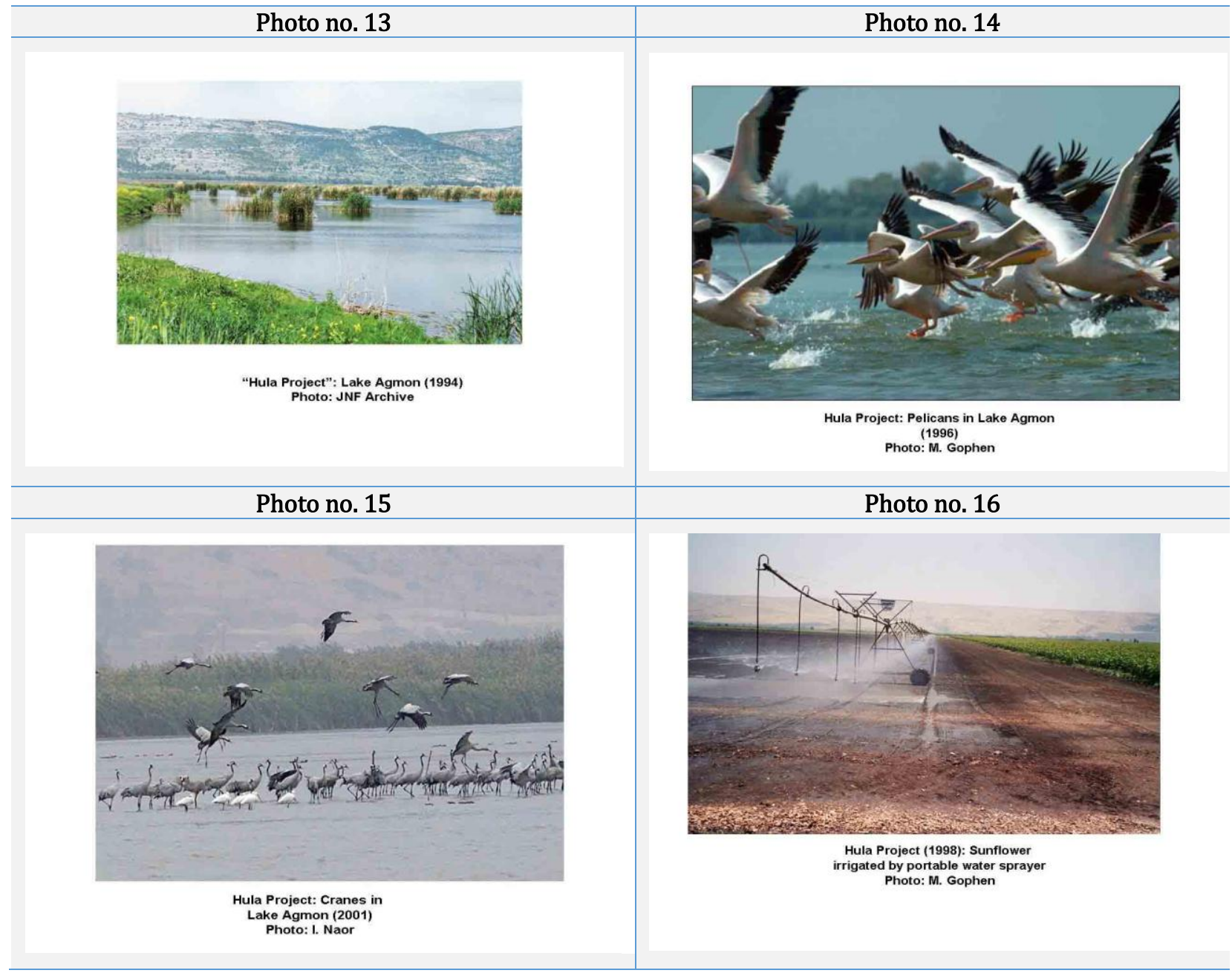




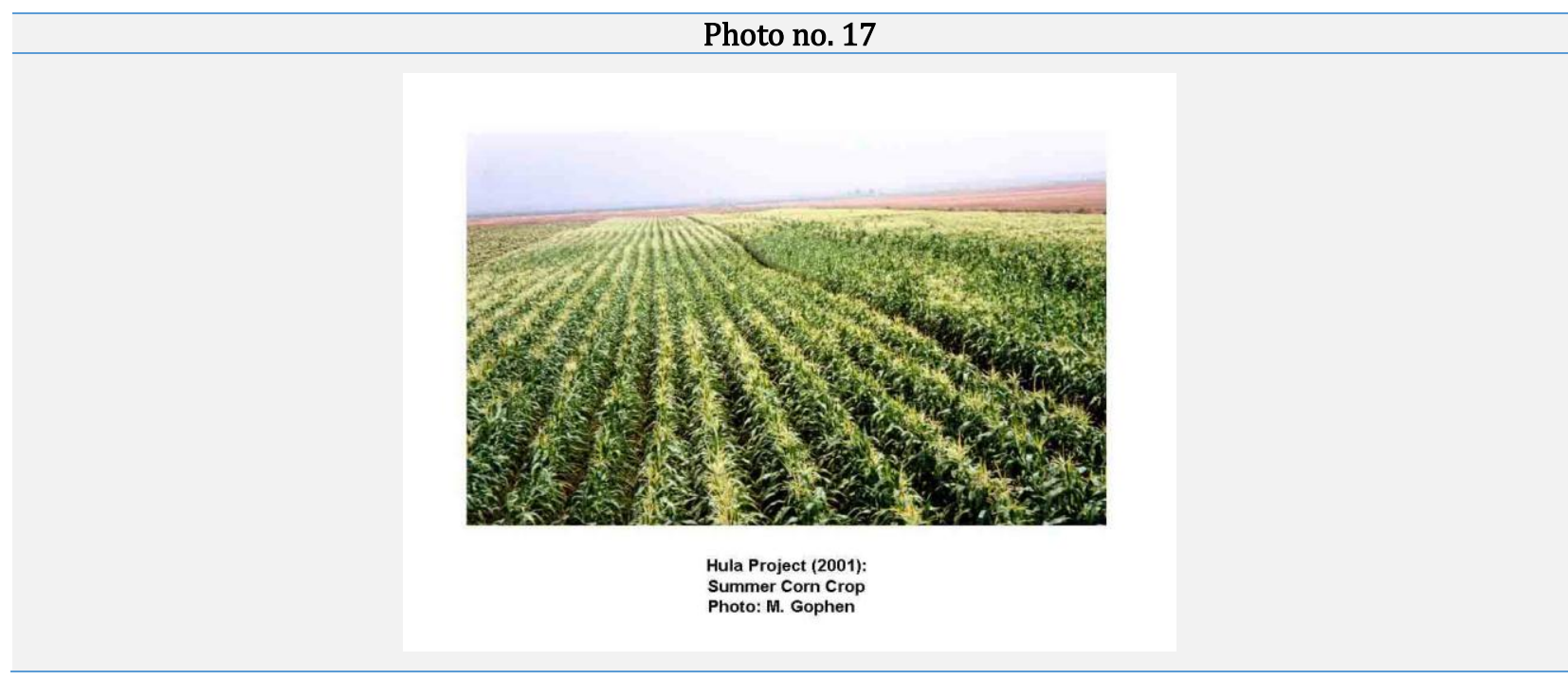

\subsection{Summary and conclusion}

\subsection{The contribution of the study to future policy implications}

Before drainage of the Lake Hula and adjacent Swamps, the population size in the Kinneret-Jordan (including all headwater sources) basin was approximated as 1000-2000 residents while presently -above 250000 , mostly in the Hula Valley.

The Hula Valley Land utilization before drainage was extensive while presently, the entire valley is intensively cultivated.

Tourism before drainage included solitary visits of individual explorers or small delegations while presently about half a million tourists, bird watchers, and farmers are visiting and $\backslash$ or staying and work in the Valley.

Villages and towns in the Valley and in close vicinity were only few before drainage whilst presently about 100 . Agricultural products cultured in the Hula Valley are presently distributed locally and through national and international markets while before drainage, this type of production was generally maintained seasonally for local consumption.

Before drainage, the Hula Valley water resources were migrated through the valley into Lake Kinneret and downstream into the Dead Sea and usage was low. After drainage, most of those water sources are stored in Lake Kinneret and conveyed for national consumption throughout the entire part of the state of Israel for human consumption for domestic (including drinking), agricultural development and industrial usage. Nevertheless,

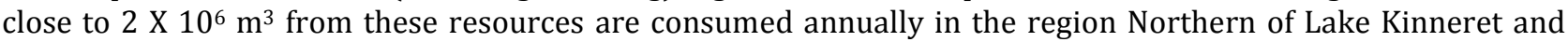
locally in vicinity to Lake Kinneret.

Before drainage, $100 \%$ of the Hula Valley was occupied by the Lake, Swamps and seasonal floods while currently just about $10 \%$ of the valley is occupied by Lake Agmon and other small bodies of water for fish ponds and ecotourism, and $70 \%$ of the valley is dedicated for field crops cultivation, $18 \%$ for orchards and other crops $2 \%$ un-cultivated. The valley is fully green covered throughout a full annual cycle.

Number of native birds recorded in the valley was about 200 (Dimentman et al 1992) before drainage while close to 300 species were recently recorded, of which are the seasonal migrating 30-40000 Cranes, 40000 Pelicans , and 40000 white storks which are the major tourists (and bird watchers) attraction.

The current diversity of agricultural crops is significantly larger than what it was before drainage, and the production efficiency is significantly higher.

The current control on fluxes of nutrients from the Hula Valley into Lake Kinneret is much better than during the period before drainage resulted by hydrological improvements and environmental management.

No any Malaria infection case was recorded after completing the drainage implementation. 
National and International visitors are coming to the Hula Valley to take part in cultural and natural festival events or professional conferences as well as the establishment of an Academic College and Scientific Research institute in the Hula Valley and tin vicinity.

The Hula Valley and adjacent land is now open for accepting more residents resulted by constructions of transportation and industrial facilities.

The major component of livestock in the Hula Valley before drainage was a few thousands of Water Buffaloes staying mostly in bodies of water giving minor benefits of meat and milk while presently about 25000 cows are cultured within the Valley and in close vicinity, for meat production based on nutrition of natural grass grazing with minimal additional food items.

In conclusion, it can be stated that the drainage of the Hula Valley contributed remarkable improvement of advanced infrastructure for human welfare living in this region. The present environmental conditions and utilization policy in the Hula Valley justify the success of anthropogenic intervention concept resulted in ecosystem services aimed at human welfare.

\section{Acknowledgment}

The research leading to these results has received funding from the European Union's Seventh Framework Programme FP7- REGPOT-2012-2013-1, Agreement n. 316157/.

\section{References}

Ben-Porath, A., and Minsker, N. (1996). The Hula Drainage: What we learn from the History of 160 Years? Maim VeHashkaya, Vol. 361. pp 42-48, (in Hebrew).

Dimentman, Ch., Bromely H.J. and Por, F. D. (1992). Lake Hula, Reconstruction of the Fauna and Hydrobiology of a lost Lake. The Israel Academy of Sciences and Humanities, Jeusalem. $170 \mathrm{p}$.

Gophen, M. (2015a). Management Improvement of the Agmon Wetland System (Hula Valley, Israel) aimed at Enhancement of Bird Population and Kinneret Protection. Open Journal of Modern Hydrology, 2015, 5, 1-9. http://dx.doi.org./10.4236/ojmh.2015.51001.

Gophen, M. (2015b). Nitrogen and Phosphorus dynamics in the Shallow Lake Agmon (Hula Valley, Israel), Open Journal of Ecology, 2015, 5, 55-65. http://dx.doi.org./10.4236/oje.23015-53006.

Gophen, M. (2016). Chemical, Hydrological and Climatological Properties of Lake Agmon, Hula Valley (Israel), (1994- 2006). Open Journal of Modern Hydrology, 2016, 6, 8-18. http://dx.doi.org/10.4236/ojmh.2016.61002.

Gophen,M., Meron, M. Orlov-Levin, V, Tsipris, Y., (2014), Seasonal and spatial distribution of N \& P substances in the Hula Valley (Israel) subterranean. Open Journal of Modern Hydrology; 4, 121- 131. http://dx.doi.org./10.4236/ojmh.2014.44012.

Karmon, Y. (1956). The Northern Huleh Valley, Its Natural and Cultural Landscape; The Magnes Press, The Hebrew University, Jerusalem; 108 p. (in Hebrew).

Neuman, J. (1955). On the water balance of Lake Huleh and the Huleh Swamps 1942\43 - 1946\47; Israel Exploration Journal, Vol. 5, No.1, 1955.Isrel Meteorological Service Series D., Contribution No. 5. pp 49-58.

Ritter, C. (1850). Die Erdkunde von Asien. Bd. viii. 2. Abt. 2. Abschnitt. 1. Abt.: Palastina und Syrien. 2. Aufl. Berlin. 140 p.

Tristram, H. B. (Henry Baker) 1822-1906 (1865). The Land of Israel. A journal of Travels in Palestine. London, Society of Promoting Christian Knowledge, p.714. 